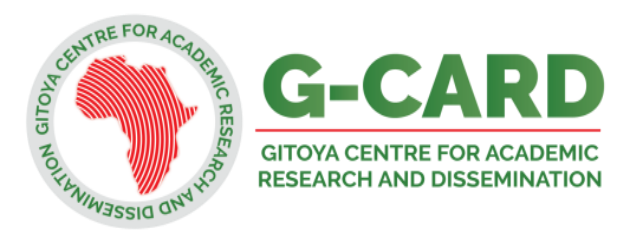

\title{
Enhancing Guidance and Counselling Services for Mitigating Psychosocial Distress among University Students in Tanzania
}

\author{
${ }^{1}$ James Ololo Otieno and ${ }^{2}$ Dr. Catherine K. Simiyu \\ ${ }^{1} \mathrm{PhD}$ student, Department of Educational Psychology, Moi University-Kenya \\ ${ }^{2}$ Department of Educational Psychology, Moi University- Kenya \\ Corresponding Author: jemotieno83@gmail.com
}

\begin{abstract}
This study investigated the strategies for enhancing guidance and counselling services in an effort to mitigate psychosocial distress in Tanzanian Universities. The study adopted a qualitative approach. Multistage and purposive sampling techniques were used to select the study participants. Two universities, two counsellors and two Deans of Students were purposively selected while eighteen students, nine from each university were sampled on the willingness basis for group discussion across the faculties. Data was collected using focus group discussion and interview schedule. For content validity, the inter-raters established the viability of the instruments in view of the research question. Reliability was ensured through multiple data collection instruments. Data was analyzed thematically. The study established that peer counselling programs were not formalized in universities in Tanzania. It can also be concluded that students were not informed about the availability and benefits of guidance and counselling services available in universities and the guidance and counselling departments were underfunded by the universities. Moreover, the counsellors were not professionally trained in counselling. The study recommended that Universities should employ professional counsellors, adequately fund the guidance and counselling services for efficient services. Besides, orientation programs should include informing new students about available guidance and counselling services on campuses.
\end{abstract}

Keywords: Counselling, Guidance, Mitigate, and Psychosocial distress, peer counselling

\section{Introduction}

Guidance and counselling is a professional service aimed at assisting students to understand themselves, others and the school environment as well as to attain abilities to adjust accordingly (Gulo, Olel \& Oanda, 2011). The essence of guidance and counseling in educational institutions is in that students have differing needs that may affect their learning if not addressed through guidance and counseling programs. In addition, once students get into the university, they are independent and in most cases are away from their parents or guardians. Some students are not able to cope with this new environment and some may resort to antisocial behaviors such as taking drugs and indulging in illicit sex. Guidance and counselling services therefore are so significant in such situations in order to help students facing these new challenges.

Guidance and counseling helps learners adjust to their environments and develop the right attitude and set individual goals that will enhance improvement of their educational programs while in school and even in their post school life. According to Cooper (2007), guidance and counselling focuses on preparing students for unanticipated life events and ongoing personal difficulties and challenges that they face in educational institutions. Bogba (2016) posits that effective guidance and counselling programs are important to the university climate and constitute a crucial element in improving students' achievement.

University life is associated with experiences of significant stressors to students that include stress 
experienced by new life of transiting into that education level. Triggers to these stress factors can be linked to increased academic demands, constrained finances and personal relationships (Julal, 2013). The challenges can have major effects on the student experience that include negative academic performance.

A university-based study conducted in Tanzania by Onditi, Ikupa and Masath (2014) on Psychosocial Stressors and help-seeking behavior among undergraduate Student teachers in Tanzania at Dar es Salaam University College of Education indicated that despite the existence of college formal help or support resources, their utilization by students was low. This is also consistent with another universitybased study by Kalonge (2007) which reported that students from the University of Dar es Salaam Mwalimu Nyerere campus were overwhelmed by many stressors but seemed not willing to seek professional help from guidance and counselling offices.

Despite the fact that counselling is important to university students, it has been documented that only a minority of students who experience psychological distress seek professional counselling (Raunic \& Xenos, 2008). The authors' report on utilization of counselling services rate by local and international students in America, showing that only a very small percentage between $2 \%$ and $4 \%$ of university students accessed counselling services and in which case females were more likely to use them than males. Kambouropoulos' (2008) study of 90 international students at two Australian universities found that the students do not adequately utilize counselling services despite the extreme concerns they face in relation to academic, social and emotional well-being.

While the statistics confirmed that students and counsellors were of similar views; that female students sought counselling services more than male students in the universities, a study by Kamunyu, Ndungo and Wango (2016) noted that both male and female students are not fully utilizing counselling services. Most of those seeking help were female students at $91.5 \%$ while males were much fewer at $8.5 \%$. The male students were not utilizing counselling services for fear of violating masculine ideologies.

In realizing the need for guidance and counseling, The Ministry of Education and Culture (MOEC) in Tanzania made efforts to institutionalize guidance and counselling services in the education system. MOEC established guidance and counselling services in secondary schools and colleges through Education Circular Number 11 of 2002. The main objective was to help students to acquire proper knowledge and information so that they are able to make rational decisions while they are at school (United Republic of Tanzania, 2002). Despite the government's effort, guidance and counselling services are underutilized by students in Tanzania.

A plethora of studies within and without Tanzania report the availability of guidance and counselling departments in universities (Amani \& Sima, 2015; Eliamani, Mghweno, \& Baguma, 2014; Hayes \& Morgan, 2011; Owino, 2015). In spite of this, majority of the students do not seek these services for support (Dimalaluan, Anunciado, \& Juan, 2017) and instead seek help from intimate friend and relatives which may not be entirely helpful to enable them to cope with stress experienced in the institutions (Kalonge, 2007 as cited in Onditi, Ikupa and Masath, 2014). Furthermore, little research has been done to establish measures that can enhance guidance and counselling services in mitigating psychosocial distress among university students. This study sought to provide answer to the following research questions:

1. To what extent is peer counselling implemented among the universities under investigation?

2. What is the university counsellors' qualification?

3. What is the level of students' awareness of the existing guidance and counselling services in the universities?

4. What is the extent of funding of the guidance and counselling services by the universities?

\section{Research Methodology}

This study employed qualitative approach whereby the preformed opinions of students, counsellors and Deans of students on how to enhance guidance and counselling services in Tanzanian universities were described. Universities in Tanzania were categorized into two groups: Private and Public chartered universities. From each stratum, one was purposively sampled based on reported cases related to psychosocial distress in those universities and the researcher's personal experience when doing counselling practicum in one of the selected universities. One student counsellor and Dean of students from each university were also purposively 
sampled. Nine students from each university were sampled across all the faculties on the basis of their willingness to participate in the Focus Group Discussion.

Structured interview schedule and focus group discussion were used to collect data. Interview was conducted with the Deans of Students and counsellors. This type of interview gives the researcher opportunities to probe for views and opinions of the interviewee (Gray, 2004 as cited in Koskei \& Simiyu, 2015). Focus group discussion was done with students. To increase the validity of the instrument, the questions were framed in the least ambiguous way under the guidance of the research experts. Reliability was ensured through the use of multiple instruments that is the interview schedule and the focus group discussion. Thematic analysis was applied to analyze the data. According to Neuendorf (2019), thematic analysis produces a depth of understanding of the meaning of a set of texts. This was an added advantage for such qualitative studies as this.

To ensure maximum confidentiality and anonymity, pseudonyms for the names of students, counselors, and Deans of Students were used throughout the study. Respondents' data was also treated with ultimate confidentiality during and after the collection of data. Research participants and the institutions sampled for this study therefore remained anonymous.

\section{Findings and Discussion}

The research questions were handled using qualitative data. The data was obtained through interviews and FGD with counsellors, Deans of Students and students. From the interviews and FGD, the information gathered was categorized in specific themes and presented through guiding research questions.

Research Question One: To what extent is peer counselling implemented in the universities under investigation?

The interview with participants revealed the absence of peer counselling in the universities. When their opinions were sought on how to enhance guidance and counselling, one of the counsellors had this to say;

There are no peer counsellors among students who can help students resolve their problems without presenting them to counsellors but they are important so universities should identify students and train them on basic counselling skills so that they can help their fellow students when faced with stressors but cases that they cannot handle they send to counsellors" (Counsellor, Private University).

This means that all cases that would have been handled by peer counsellors were taken to the counsellors and given their small number they were not able to handle the many students effectively, thus most students didn't get attended to by counsellors when faced with problems that they could not resolve, leading to psychosocial distress.

Regarding peer counselling, the finding of current research suggested that peer counselling should be strengthened in universities. Normally whenever students are faced with such problems as family, social, economic, financial, health and academics, they often look for help from the nearest persons whom they are comfortable with. Peer counsellors would act as ambassadors of the guidance and counselling departments and would also help in raising students' awareness of the available guidance and counselling services on campus, thus promote consumption of the services by students. The result of this study replicates Hlongwane (2006) who emphasized the essentiality of peer counselling where there is shortage of guidance and counselling staff to deal with requests for help from students in distress. The author adds that as a student support wing and peer counselling have helped in attracting more students to come for counselling and have certainly enriched staff understanding and knowledge of students. Moreover, peer counsellors can aid counsellors in promoting outreach programs such as an Education Fair, a Mental Health Exhibition and other activities (Low, Kok \& Lee, 2013).

Research Question Two: What is the qualification of the university counsellors?

The interview with Deans of Students revealed that universities don't employ professional counsellors, and no further training was done to the available counsellors in the universities. When the question was posed on what can be done to improve guidance and counselling in universities, this is what one of the Deans of Students had to say; "the universities should employ counsellors who are experts in the field of counselling and even those who are already employed should be taken for inservice training on counselling because some have 
not done counselling as a profession" (Dean of Students, Public University). This sentiment alluded to the fact that professionalism in guidance and counselling services did not exist in universities of Tanzania that were selected for this study, yet it is a fundamental requirement for students' appropriate behavior and maximized academic achievement.

Quality Guidance and counselling services offered by qualified counsellors win the confidence of the students and encourage them to seek help when faced with problems they cannot solve. This would result in mitigating psychosocial distress in universities. The findings are supported by results of a research done in Ethiopian Universities by Seyoum (2011) who suggested that there is need to have more professional counsellors in university campuses to conduct more individual counselling and a greater number of interventions with students' problems. Ulrich and Smallwood (2011) recommended that a short course in psychology and or any other related discipline would be necessary for the good performance of the counsellor. The need to have professional counsellors in universities is also supported by a number of authors (K'okul, 2010; Standa, 2000; Vidal, Diez \&Vieira, 2003).

Research Question Three: What is the level of students' awareness of the existing guidance and counselling services in the universities?

In the FGD with students from both public and private universities studied, it was revealed that universities should put up awareness campaigns to popularize guidance and counselling services among students. When the question was posed on what can be done to improve guidance and counselling in universities, this is what some discussants had to say; "If the services are there, they are not known, we should be made aware of such" (Student, Public university).

"We should be told about where the guidance and counselling office is and the services offered there so that we know who to see when we have problems. I normally go to my lecturers when I have a problem" (Student, Public University).

This means that there are some students within the university who didn't know that there was guidance and counselling services in the universities and that is why they probably didn't seek for help. Therefore, there is need to promote awareness of guidance and counselling services in order to promote positive perception and consumption of the services among students in Tanzanian universities. Where counselling is available, it is essential to develop mechanisms for conveying to clients the information about their availability. This can be done through written materials such as leaflets, posters and websites, face-to-face contact and peer support groups. Having enough information about the services can enhance positive perception towards the services and the readiness to seek help. When students are aware of the services, they are likely to seek help when faced with problems (Eisenberg, Gollust, Golberstein \& Hefner (2007; K'okul, 2010). This suggestion is supported by Agi (2015) who opined that while lack of awareness of counselling is prevalent in schools, this trend could be reversed through activities like talks on guidance services, displays of guidance materials, posters and letters to parents, use of bulletin boards, private interviews, seminars, workshops and conferences. The importance of creating awareness about the guidance and counselling services on campus established in the current study echoes previous studies (Cebi, 2009; Chan \& Quinn 2012; Gaughf, Smith \& Williams, 2013). While the students are the focus of the guidance programs in universities they should therefore be made to understand and appreciate the various objectives of guidance and counselling.

Research Question Four: What is the extent of funding of the guidance and counselling services by the universities?

In the interview with the counsellors, it was established that guidance and counselling departments are underfunded and it was suggested that universities should adequately fund the guidance and counselling service to realize quality services. When a question was posed on measures that can promote consumption of guidance and counselling services, this is what one counsellor said;

The university administration should provide enough money so that we are able to organize events like career fairs and outreach activities which will attract students and improve the quality of services we offer. Without enough money, we cannot do much (Counsellor, Public University).

This implies that adequate funding can lead to provision of quality guidance and counselling services. For the counsellors to perform their functions effectively, adequate fund is needed to build structures, procure equipment and tools, and 
organize workshops and seminars in addition to manpower development. This therefore calls for adequate funding of the guidance and counselling departments to promote quality and efficient operations of guidance and counselling service delivery and consequently enhance students' positive perception and consumption of guidance and counselling services. The suggestion is supported by Kitzrow (2009) who opined that at the institutional level, the active support of top level administrators who are willing to consider mental health needs a priority. It could be argued that sufficient funding of the guidance and counselling operations would enable the counsellors to buy enough counselling materials, organize psychoeducation seminars and carry out publicity programs about the availability of the services on campus. It is probable that adequate funding of the guidance and counselling departments will improve the quality of the services which would in turn promote consumption of the services by students.

\section{Conclusion and Recommendations}

This section gives the conclusions of the study and then comes up with recommendations.

\section{Conclusions}

The study concludes that universities have not implemented peer guidance and counselling services, hence cases are presented to the few counsellors leading to heavy workload which can result to counsellors' burnout. Besides, guidance and counselling departments are not well funded by the universities, hence the quality of the services is compromised. Moreover, the rate of students' awareness of the existing guidance and counselling services in the universities is low, which shows that orientation for new students is not well done. Furthermore, It can also be concluded that the universities don't have qualified professional counsellors, which may affect the quality of the services they provide leading to prevalence of psychosocial distress among students.

\section{Recommendations}

The researchers recommend that university administrations should adequately fund the guidance and counselling departments and employ professional counsellors for quality services in a bid to mitigate psychosocial distress among university students. Besides, universities should provide information on guidance and counselling services available on campuses during the orientation to new students for students to be informed about the services, hence seek help when faced with problems. Moreover, the university administrations should formalize peer counselling in the universities because students may prefer sharing their problems with peers than with adults.

\section{Reference}

Agi, C. W. (2015). Evaluation of student' perception of school counselling and their attitudes towards its programmes. Arabian Journal of Business and Management Review, 2, (5), 103-110.

Amani, J., \& Sima. R. (2015). The status of career counselling services in higher learning institutions in Tanzania. International Journal of Education and Social Science, 2, (8), 19-27.

Bobga, T. J. (2016). An appraisal of effective Provision of guidance and counseling services in Cameroon state universities; Trends and challenges. International Journal of Humanities Social Sciences and Education (IJHSSE), 3(9), 75-90.

Cebi, E. (2009). University students' attitudes toward seeking psychological help: effects of perceived social support, psychological distress, prior help-seeking experience and gender. (Unpublished PhD thesis).Middle East Technical University, Turkey.

Chan, S., \& Quinn, P. (2012).Secondary school students' views of inhibiting factors in seeking counselling. British Journal of Guidance \& Counselling, 40, 527-543.

Cooper, M. (2007). Student Support Services at Community College: A Strategy for Increasing Student Persistence and Attainment. Institute for Higher Education Policy.

Dimalaluan, A. B., Anunciado, M. V., \& Juan, N. N. (2017). Problems and difficulties encountered and training needs of college students: Basis for improving guidance and counselling services. Asia Pacific Journal of Multidisciplinary Research, 5(1), 167-172.

Eisenberg, D., Gollust, S. E., Golberstein, E., \& Hefner, J. L. (2007). Prevelence and correlates of depression, anxiety and suicidality among university students. American Journal of orthopsychiatry, 77(4), 534-542. 
Eliamani, P, E, Mghweno, L. R., \&, Baguma, P. (2014). Access to guidance and counseling services and its influence on students' school life and career choice. African Journal of Guidance and Counselling, 1, 07-015.

Gaughf, N. W., Smith, P. L., \& Williams, D. A. (2013). Faculty and student perceptions of academic counselling services at an academic health science center. Perspect Med Educ, (2), 165-170. doi: $10.1007 /$ s40037-013-0056-1.

Gudo C.O., Olel, M.A., \& Oanda, I.O. (2011).University Expansion in Kenya and Issues of quality Education: Challenges and Opportunities. International Journal of Business and Social Science, 2 (20), 54-62.

Hayes, C. \& Morgan, M. (2011). Research on the Practice of Counselling by Guidance Counsellors in Post Primary Schools. Dublin: National Centre for Guidance Education.

Hlongwane, M. M. (2006). An inquiry into counselling interventions and student support systems at a university in transition. (Unpublished PhD Thesis). University of Zululand, South Africa.

Kalonge, B. M. (2007). The provision of students counselling services at the University of Dar es salaam in the context of university of Dar es salaam transformation program (Unpublished master's dissertation). University of Dar es Salaam, Tanzania.

Kamunyu, R. N., Ndungo, C., \& Wango, G. (2016). Reasons why university students do not seek counselling services in Kenya. Journal of Education and Practice, 7(15), 142-145.

K'okul, F.S. A. (2010). Perceptions of students on the status of guidance and counselling in selected universities in Kenya for minimizing student riots. (Unpublished PhD Thesis) Kenyatta University, Kenya.

Koskei, B., \& Simiyu. C. (2015). Role of interviews, observation, pitfalls and ethical issues in qualitative research methods. Journal of Educational Policy and Entrepreneurial Research (JEPER), 2, 108-117.

Julal, F. S. (2013). Use of Student Support Services among University Students: Associations with Problem- Focused Coping, Experience of Personal Difficulty and Psychological Distress. British Journal of Guidance \& Counselling, 41 (4), p.414-425.

Kalonge, B. M. (2007). The provision of students counselling services at the University of Dar es salaam in the context of university of Dar es salaam transformation program (Unpublished master's dissertation). University of Dar es Salaam, Tanzania.

Kambouropoulos, A. (2008). The cross cultural counselling experience: An investigation of perspectives of international students and counsellors. (Unpublished doctoral dissertation). Monash University, Melbourne.

Kitzrow, M. A. (2009). The mental health needs of today's college students: Challenges and recommendations. NASPA Journal, 46, 646660.

Low, S. K, Kok, J. K., \& Lee, M. N. (2013). A holistic approach to school-based counselling and guidance services in Malaysia. School Psychology International, 2, 190-201.doi: 10.1177/0143034312453398

Neuendorf, K. A. (2019). Content analysis and thematic analysis. In Brough, J. (Eds.), Advanced Research Methods for Applied Psychology: Design, Analysis and Reporting. (pp 225-234). New York: Routledge.

Onditi, H, Z, Ikupa, M., \& Masath, B. F. (2014). Psychosocial stress and help-seeking behavior among undergraduate student teachers in Tanzania. International Journal of Learning \& Development, 4,70-90. Retrieved from https://www.macrothink.org

Owino, E. A. (2015). Assessment of service delivery in guidance and counselling units in selected secondary schools in Eldoret municipality, Kenya. Journal of Education and Practice, 6(19), 29-42.

Raunic, N., \& Xenos.W. (2008). University Counselling Service Utilisation by Local and International Students and User Characteristics. Melboune: Springer.

Seyoum, Y. (2011). Revitalizing quality using guidance counseling in Ethiopian higher educationinstitutions: Exploring students" views and attitudes at Haramaya 
University. International Journal of United Republic of Tanzania. (2002). Waraka wa Instruction, 4(2).

Elimu namba 11 wa Mwaka 2002:

Standa, E. (2000). Report of the Vice Chancellors' Kuanzisha Huduma za Malezi na Ushauri Committee on the Causes of Disturbance/Riots in Public Universities. Nairobi: Jomo Kenyatta Foundation.

Ulrich, D., \& Smallwood, B. (2011). Leadership competencies for development: For developing actions for self-empowerment. Nasaha kwa Wanafunzi Katika Shule na Vyuo Vya Ualimu. Dar es Salaam: Ministry of Education and Culture.

Vidal, J, Diez, G., \&Vieira, M, J. (2003). Guidance services in Spanish universities. Tertiary Education and Management, 9(4), 267280.doi: 10.1080/13583883.2003.9967109 